\title{
Tourism and empirical applications of international trade theory: a multi-country analysis
}

\author{
ALLAN W EBSTER \\ Professor of Finance, The Business School, B ournemouth U niversity, Talbot Campus, \\ $F$ en Barrow, Poole BH 12 5BB, UK. \\ JOHN FLETCHER \\ Professor of Tourism, International Centre for Tourism and $\mathrm{H}$ ospitality Research, \\ B ournemouth U niversity, Tal bot Campus, Fern Barrow, Poole B H 12 5B B, UK. \\ E-mail: jeflech@bournemouth.ac.uk. \\ PHILIP HARDWICK \\ Professor of Economics, The B usiness School, B ournemouth U niversity, \\ Talbot Campus, Fern Barrow, Poole B H 12 5B B, UK.

\section{YEGANEH MORAKABATI} \\ Senior Research A ssociate, School of Services M anagement, Bournemouth U niversity, \\ Talbot Campus, Fern Barrow, P oole B H 12 5B B, UK.
}

This paper examines the application of quantitative techniques to further our understanding of international trade theory with respect to tourism flows. The analyses are based on the construction of Balassa and Grubel-Lloyd Indices, as well as the construction of dynamic indices. The results of the analyses suggest that international trade theory has much to offer the study of international tourism flows. Many countries seem to specialize as both exporters and importers of tourism services. The analyses also explore the theoretical assertion that intra-industry trade is likely to be of importance in understanding international tourism flows.

Keywords: international trade theory; Balassa Index; Grubel-Lloyd Index; revealed comparative advantage; dynamic indices of intraindustry trade

The relevance of the theory of international trade to the economics of tourism has been recognized for some time. For example, Sinclair and Stabler (1997), like a number of other authors, discuss the relevance of comparative advantage 
theory to international specialization in tourism. Moreover, they al so emphasize the role of more recent trade theories - those of intra-industry trade - based on imperfect competition, product differentiation and scale economies. The starting point of our paper, in consequence, is that the case for applying international trade theory to tourism has al ready been well made in terms of theoretical arguments. It is not, therefore, our intention to contribute further to these theoretical discussions but to focus upon empirical applications of international trade theory.

There are a number of empirical techniques arising from attempts to measure and test key theoretical aspects of international trade. To the extent to which international trade theory provides a useful framework for the analysis of tourism, these empirical techniques are also likely to provide a basis for understanding international tourism. However, to the best of our knowledge, very little work exists which seeks to apply the empirical techniques of international trade to tourism, particularly for a multicountry sample. The main objectives of this paper, therefore, are to provide a quantitative trade analysis of international tourism and to assess how far applying these techniques to international tourism is useful.

\section{Previous empirical research on international tourism}

$\mathrm{H}$ istorically, there have been very few multicountry empirical studies of comparative advantage and intra-industry trade for the service sectors. A key reason for this has been the absence of international data on trade in services, measured on a consistent basis across countries. Indeed, to the knowledge of the authors, there remains no suitable world database of international trade in services that compares to those available for international trade in goods. The comparati vely recent introduction of a database of international trade in services for OECD countries has resulted in the recent appearance of multicountry studies of comparative advantage in services. One example is the paper by $\mathrm{H}$ ardwick and Webster (2005).

International tourism flows have grown strongly throughout the latter half of the 20th century and the early years of the 21st, in spite of some major obstacles encountered on the way, particularly the recently experienced growth of terrorist activities, natural disasters and growing threats to health. As international tourism flows have increased, so too have the number and scope of countries becoming involved in this trade. Although $100 \%$ of all international tourism flows was attributable to just 15 countries in the 1950s, by the end of the 20th century, tourism was a part of the trade balances of most countries and the top 15 countries accounted for only $60 \%$ of all international flows. Furthermore, the ranking of the top countries in terms of international tourism flows has also been a dynamic affair, with countries from Asia and Central/Eastern Europe entering into the top rankings for the first time (for example, China ranked 7th in tourism receipts in 2004; Luzzi and Fluckiger, 2003).

Table 1 shows tourism receipts, GDP and exports for countries ranked at the top and bottom of tourism flows. It can be seen that, in terms of tourism receipts as a percentage of GDP, countries at both ends of the tourism flow 
Table 1. Selected top and bottom rankings of countries with respect to tourism flows (2003).

\begin{tabular}{lcrrrr}
\hline Country & $\begin{array}{c}\text { Tourism } \\
\text { receipts } \\
\text { (US } \mathbf{~ m )}\end{array}$ & $\begin{array}{c}\text { GD P } \\
\text { (U S } \mathbf{~ b n )}\end{array}$ & $\begin{array}{c}\text { Tourism } \\
\text { receipts } \\
\text { \% of GD P }\end{array}$ & $\begin{array}{c}\text { Exports } \\
\text { \% of } \\
\text { GDP }\end{array}$ & $\begin{array}{c}\text { Tourism } \\
\text { receipts } \\
\text { \% of exports }\end{array}$ \\
Top & & & & & \\
USA & 64,348 & 11,000 & 0.5850 & 9.6 & 6.0938 \\
Spain & 39,645 & 881 & 4.5000 & 26.3 & 17.1103 \\
France & 36,593 & 1,800 & 2.0330 & 25.7 & 7.9105 \\
Germany & 23,106 & 2,400 & 0.9628 & 35.5 & 2.7121 \\
UK & 25,565 & 1,800 & 1.4203 & 25.4 & 5.5916 \\
Bottom & & & & & \\
Dem. Rep. Congo & 1 & 5.70 & 0.0175 & 22.4 & 0.0783 \\
Burundi & 1 & 0.60 & 0.1667 & 6.8 & 2.4510 \\
Guinea-Bissau & 2 & 0.24 & 0.8333 & 32.4 & 2.5720 \\
Solomon Islands & 2 & 0.23 & 0.8696 & 41.9 & 2.0753 \\
\hline
\end{tabular}

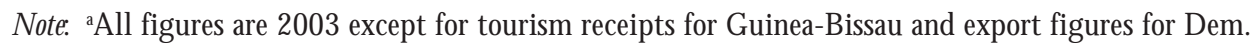
Rep. Congo.

Source: A dapted from W TO (2006) and W orld Bank (2006).

spectrum have variable levels of dependency on tourism, with Spain recording the highest proportion of GDP attributable to tourism receipts, followed by France and then the UK. However, the Solomon Islands owe al most as much of their GDP to tourism receipts as Germany, and more than the USA. Of course, the economic diversity of those countries registered as being in the top ranking will explain the relatively low proportion of GDP attributable to a single form of economic activity such as tourism. H owever, in terms of exports, the Solomon Islands has the most open economy, where exports are responsible for $41.9 \%$.

W ith respect to how much of a country's exports are attributable to tourism receipts, the final column of Table 1 shows that more than $17 \%$ of Spain's exports are as a result of international tourism, whereas for the Congo the proportion is negligible. Interestingly, although the USA data reveal that tourism represents the smallest proportion of GDP out of these countries, it ranks third when it comes to the percentage of exports attributable to international tourism receipts. There seems to be much greater variation between the top ranking countries than there does between the lower ranking countries which, with the exception of the Congo, vary from $2.1 \%$ to $2.59 \%$ of exports being attributable to international tourism receipts.

This paper focuses on the reasons that explain why some countries specialize more in international tourism than others. Is it because of natural endowments of factors relating to the production of tourism, general economic activity levels, or some other factor?

Much of the empirical research into international tourism flows has been focused on competitive advantage, rather than comparative advantage. As such, is has been based on demand functions and, therefore, factors that influence the 
demand for tourism services between specific countries. These factors then assist in constructing demand equations to be used in forecasting models (see, for example, Turner and Witt, 2001). Few have attempted to explain, from a theoretical point of view, the rankings of international tourism activity. The complexity of tourism, drawing on general factors of production (land, labour and capital ), plus the normally non-traded factors such as climate, environment, infrastructure and sociocultural capital, make the industry difficult to examine using traditional international trade theory. Indeed, the fact that many of tourism's factors of production do not conform to the usual supply constraints and utilization scenarios normally associated with factors of production make it a challenging goal. In addtion, the fact that international tourism means that countries can trade normally non-tradable commodities increases the complexity.

Some authors (such as Gooroochurn and Sugiyarto, 2005) have attempted to anal yse the competitiveness of the international tourism industry using data for more than 200 countries and creating an aggregate index which incorporates the environment, human resources, human tourism, infrastructure, openness, price, social development and technology. Of these eight indicators of competitiveness, it was found that the social and technology indicators carried the greatest explanatory power, whereas the human tourism and environment indicators yielded the lowest explanatory power. A brief examination of the structure of these variables provides some insight to what may be, on the surface, a surprising result. The social and technology indicators are composite variables associated with development, whereas other variables such as the environment are more narrowly and economically ambiguously identified (population density, $\mathrm{CO}_{2}$ emissions and ratification of treaties).

Other authors, such as K han and Lin (2001), have attempted to establish a relationship between general trading activities and the level of international tourism. In a study of cointegration and causality in Singapore, they found that there did seem to be a significant relationship between business travel and the volume of trade (globally, business travel accounts for around $20 \%$ of all international trips), whereas there was no evidence for such a relationship when testing international leisure trips. It was interesting to see that the causality between total trade and business travel seems to run in both directions, which brings with it implications for tourism policy.

Turning attention towards comparative advantage theory, it can be seen that traditional international trade theory was constructed to explain the movement between countries of goods rather than intangible products, referred to as services. The traditional theory of comparative advantage uses the differences in relative factor endowments between countries to explain the rationale for international trade where countries have a comparative advantage in those goods that rely on the factors of production that are in relative abundance. Given the fact that international tourism is perceived as a labour-intensive industry, it would seem logical that countries experiencing a relative abundance of underutilized labour, combined with an abundance of environmental resources (more difficult to identify unambiguously), have a comparative advantage in the export of international tourism services for the leisure market. It is possible to identify many countries that fit this description, such as those found in the Caribbean and the South Pacific. However, one would not normally expect to 
find countries such as the UK being identified along with other countries that have relatively cheap labour and an endowment of natural resources. The environment or natural resources allow for almost limitless product differentiation. Add to this the differences in heritage resources, shopping facilities, etc, it is clear that there are many factors explaining the volume of tourist activity.

International tourism adds another twist to the story of comparative advantage by opening up the market for non-tradable goods. In fact, international tourism, by bringing the consumers to the producers, facilitates the inclusion of non-traded commodities in a country's export portfolio. The simultaneity of production and consumption means that tourists must travel to the destination for production to take place. If a hotel room remains empty, it is questionable whether tourism production has taken place. International tourism allows consumers to travel across borders and consume not only traded goods, but also non-traded goods. This widens the scope of the traditional comparative advantage approach; it also means that international tourism can influence the price of these non-traded commodities in ways that were previously not considered. This was a point raised by H azari and Sgro (2004). When tourists visit a destination outside of their own country of normal residence, they consume non-traded goods, such as infrastructure and superstructure, the environment and even part of the sociocultural capital. In this way, the international tourists compete with residents for these non-traded goods and, in some instances such as land or building price inflation, the effects of this can be significant.

Comparative advantage is a dynamic concept, subject to change over time. This is evident in tourism through the tourism area life cycle (TALC) models put forward by authors such as Butler (1980, see also 2006). Toh \& al (2001) used the TALC model approach when they proposed a relationship between the level of economic development of a destination and its international tourism trading patterns. In their paper, they suggested that less developed countries tended to be net exporters of tourism services (where tourist services were at the relatively early stages in the product cycle), whereas in contrast, developed countries were net importers of tourism services (being at the mature and declining stage of the cycle). H owever, such a discussion may be seen to lead back towards competitive advantage because the international tourism trade flows may be better explained by the consumption functions of populations as they move on to higher income levels.

Shan and W ilson (2001) conducted a similar study on the economy of China, postulating that there was, indeed, a causal relationship between international trade and tourism.

\title{
Techniques of empirical measurement of international trade
}

\author{
R evealed comparative advantage
}

Core concepts of international trade, such as comparative advantage, are notoriously difficult to measure. For example, a comparative advantage is defined as being the difference between two countries in relative prices under autarky (isolation from trade). Since we cannot observe autarky, and since 
relative prices are changed by the process of trade, these relative prices are inherently unobservable. Comparative advantage cannot, therefore, be directly measured.

Balassa (1965) was the first to propose a solution to this problem. He proposed the principle of revealed comparative advantage. In essence, this principle states that, to the extent that we can safely assume that observed trade flows are generated by comparative advantage, we can work back from observed flows to infer the underlying pattern of comparative advantage.

Balassa himself proposed an index for this purpose. The Balassa $\left(B_{i j t}\right)$ Index, also known as the relative export share index, is defined at time t for product i exported by country j as:

$$
B_{i j t}=x_{i j t} / x_{i w t}
$$

where $x_{i j t}$ is the share of product $i$ in country j's total exports at time $t$ and $x_{\text {iwt }}$ the share of the same good in total world exports in the same time period.

Since the essence of comparative advantage is specialization through international trade, the Balassa Index in effect measures how specialized country j is in exporting good i relative to the world as a whole. Accordingly, values of the Balassa Index of greater than unity are taken to 'reveal' a comparative advantage in good $\mathrm{i}$ by country $\mathrm{j}$ (greater specialization in the product than is typical of world trade) and values less than unity (a lesser degree of specialization than in world trade) are interpreted to 'reveal' a comparative disadvantage.

There are a range of further measures and indicators of reveal ed comparative advantage. For a more complete discussion of these, readers are referred to Ballance (1988). Of these, probably the most widely used index of reveal ed comparative advantage is the net export ratio $\left(N \in R_{i j t}\right)$. The NER for good $i$ and country $\mathrm{j}$ in time period $t$ is defined as:

$$
N E R_{i j t}=\left(X_{i j t}-M_{i j t}\right) /\left(X_{i j t}+M_{i j t}\right)
$$

where $X_{i j t}$ are country $j$ 's exports of good $i$ in time period $t$ and $M_{i j t}$ country j's imports of good $i$ in time period t.

The essence of the measure is that country $j$ is taken to 'reveal' an advantage in good i if it exhibits a positive trade balance and to 'reveal' a disadvantage if it exhibits a deficit. The larger the trade surplus or deficit in relation to total trade (exports plus imports) in good i by country $j$, the stronger the revealed advantage or disadvantage. Accordingly, the NER takes on a minimum value of -1 (country $j$ is completely specialized in importing the good) and a maximum value of +1 (country $j$ is specialized in exporting the good). Positive values are taken to 'reveal' an advantage and negative values a disadvantage.

A good discussion of the interpretation of indices of revealed comparative advantage (RCA) is provided in Ballance et al (1986). As they note, RCA indices can be used as dichotomous measures of underlying comparative advantage. That is, they can be used to determine simply whether country j has an advantage or disadvantage in the international trade of good i. RCA indices can also be used to provide ordinal measures of comparative advantage - that is, it is valid to rank RCA indices for different goods for country $j$ to assess in which goods country j's comparative advantage is strongest. Likewise, it is val id to rank RCA indices for different countries in the international trade of good i to establish 
which country has the strongest (or weakest) advantage in the good. H owever, RCA indices have no meaning as cardinal measures. There is no unit (metres, grammes, litres or otherwise) which provides a basis for cardinal measurement.

The principle of RCA also has one further major limitation. The principle states that observed trade flows can be used to make inferences about the underlying market forces that generated them. However, observed trade flows are not just the result of underlying comparative advantage but are al so, in part, the result of government interventions. Trade policy interventions such as import tariffs or similar are particularly likely to have influenced both imports and exports. For trade in goods, these government interventions introduce a margin of error in the measurement of reveal ed comparative advantage. Tourism is not typically amenable to 'direct' protectionist measures such as import tariffs or quantitative restrictions. To the extent that tourism is free of systematic subsidies, we might, therefore, expect the principle of RCA to be more reliable than for physical goods. If, of course, subsidies are widespread in tourism in many different countries, then we would need to treat RCA indices with more caution.

\section{Intra-industry trade indices}

The most widely used index of intra-industry trade (IIT) is that proposed by Grubel and Lloyd (1975). The Grubel-Lloyd Index - $G L_{i j t}$ - for good $i$ in country $j$ 's international trade during time period $t$ is defined as:

$$
G L_{i j t}=1-\left|\left(X_{i j t}-M_{i j t}\right) /\left(X_{i j t}+M_{i j t}\right)\right|
$$

where $X_{i, t}$ and $M_{i j t}$ are as defined previously. $N$ ote, that the Grubel-Lloyd Index of IIT can be rewritten as:

$$
G L_{i j t}=1-\left|N E R_{i j t}\right|
$$

where NER is the net export ratio for good i in country $j$.

The G rubel-Lloyd Index measures the extent and relative importance of IIT. It takes on a minimum value of 0 (indicating that country j's international trade in good $i$ is unidirectional) and a maximum value of 1 (indicating that country j's exports and imports of good i are exactly balanced). As such, low values are taken to imply that comparative advantage and specialization is more applicable and high values imply that IIT is the dominant form of trade. $\mathrm{N}$ ote that it is a measure of the extent of such trade, not of its determinants. It does not provide any kind of measure of the underlying causes of such trade, such as imperfect competition or product differentiation.

There have been a number of more recent developments of measures of IIT. Almost universally, these new measures have been closely related to research with respect to adjustment problems associated with changing trade flows and, in particular, with respect to labour market adjustments. In the main, they have been developed to assist in identifying how much of new trade is intra-industry in nature and, therefore, of a less disruptive type than inter-industry special ization.

The purposes of this paper are somewhat different from this literature in that we are not directly concerned with issues of economic adjustment to changes in international tourism. For this reason, we have retained the traditional Grubel-Lloyd measure (to identify the importance of intra-industry flows in a 
static sense) but have al so included a selection of these 'new' measures of IIT to provide an indication of the extent to which industry trade lies behind recent changes in international tourism.

Brülhart $(1994,2001)$ proposed a dynamic measure of IIT (normally referred to as $A_{i j}$ ) where:

$$
A_{i j}=1-\left\{\left|\Delta X_{i j}-\Delta M_{i j}\right| /\left(\left|\Delta X_{i j}\right|+\left|\Delta M_{i j}\right|\right)\right\}
$$

where $\Delta$ refers to the change in the rel evant variable. This provides a dynamic measure of IIT because it assesses the importance in overall changes in trade. Like the original Grubel-Lloyd Index, it takes on a minimum value of 0 (none of the change in trade is intra-industry) and a maximum value of 1 (all of the change in trade is intra-industry).

Menon (1996) and Menon and Dixon (1997) propose two further dynamic measures of IIT. These are normally referred to as $C_{i j}$ and $D_{i j}$, where these two measures are defined as:

$$
C_{i j}=\Delta\left(I I T_{i j}\right) /\left(X_{i j}+M_{i j}\right)
$$

where $I I T_{i j}$ is the gross value of intra-industry trade $\left[I I T_{i j}=\left(X_{i j}+M_{i j}\right)-\mid X_{i j}\right.$ - $\left.M_{i j} \mid\right]$ and:

$$
D_{i j}=\left\{2 \cdot \min \left(\Delta X_{i j}, \Delta M_{i j}\right)\right\} /\left(X_{i j}+M_{i j}\right) \text {. }
$$

The higher the value of each measure, the greater the contribution of IIT to the change in trade. $D_{i j}$ is argued by Menon and Dixon (1997) to be a more accurate measure of 'non-disruptive' trade (an issue which is not of direct concern for this paper).

For the purposes of this paper, we report all three dynamic measures, along with the traditional (static) Grubel-Lloyd Index, with the intent of measuring both the importance of intra-industry exchange in both established flows of international tourism and in recent changes.

\section{Data sources and calculation of indices}

The empirical measurement techniques of international trade - RCA and IIT indices - are frequently applied to multicountry samples of international trade in goods. In most circumstances, this requires the use of an international database to ensure the consistency of classification and data measurement across countries. To apply these techniques to international tourism, we therefore also sought to use data from a single, multicountry source.

Our data were taken from the Tourism Factbook (online) produced by the World Tourism Organization. Annual data were taken for a sample of 49 countries for the period 2000-2003 inclusive (at the time of writing, 2003 is the most recent year available for most countries). The sample of countries was selected to include, as far as possible, countries from all major geographic regions and all levels of economic development. Our sample was, in effect, reduced to a total of 44 countries because the data sets for five countries were too incomplete for practical use. Even with our remaining sample of 44 countries, there are still some gaps in the data coverage. This means that each of our main measures can only be calculated for a subsample of our full sample 
of countries, with the relevant subsample determined by the availability of the required information.

The world tourism data offer a number of different ways to measure international tourism. For most countries in our sample, data for international tourism were available according to two main bases of calculation: (a) incoming and outgoing expenditures; and (b) arrivals and departures by headcount. The data on incoming and outgoing expenditures most closely corresponded to the type of data used to calculate RCA indices for goods, but separate calculations were al so performed on the headcount measures. These provided a basis to crossreference what were essentially calculations on the value of tourism with those based on an admittedly crude measure of the volume of tourism.

The World Tourism Organization's data on tourism expenditure provide measures of total tourism expenditure. Tourism expenditure by international visitors is defined by the U nited N ations W orld Tourism Organization (UN W TO) as the expenditure of outbound visitors made in other countries, including their payments to foreign carriers for international passenger transport. This definition is better as a representation of trade in tourism because it is more extensive than the travel expenditure item usually included in the balance of payments accounts.

\section{Revealed comparative advantage - Balassa Indices}

Table 2 reports Balassa Indices of RCA for our sample of countries based on: (a) the most recent year available (2003); and (b) annual averages for the period 2000-2003. Annual averages for 2000-2003 are included to try to minimize the effects of any temporary fluctuations in the data. The different countries in the sample are also ranked according to the Bal assa Index (calculated on the 2000-2003 annual averages). This ranking is presented because RCA indices are ordinal rather than cardinal measures, as discussed earlier.

The countries ranked highest according to the Balassa Index include many for which it is not a surprise for a comparative advantage to be reveal ed. These include, for example, the Bahamas, Barbados, Cyprus, G reece and M orocco. The high ranking of Albania is, perhaps, less expected. There are a number of possible explanations for this. It needs to be remembered that the Balassa Index is based on export shares. It is possible, then, that Albania could reveal a comparative advantage without being a major 'player' in world tourism if it is of even less significance in other markets. There is some further evidence from the same data set that this is the case. For example, tourism receipts were, on average, more than $140 \%$ of the total value of the export of goods by Albania for the period 2000-2003.

It is also worth noting that in our sample of 44 countries, only 8 recorded a revealed advantage according to the Balassa Index (2000-2003 annual averages). This is normal for a study of international trade. International specialization means that for any one product or service, only a minority of countries are likely to reveal an advantage. H owever, there are some surprises with respect to those countries which 'reveal' a disadvantage according to the Balassa Index, for example, Spain and Thailand.

To some extent, this is simply the reverse of the result for Albania. That 
Table 2. Revealed comparative advantage in tourism - Balassa Indices

Country

Albania

Argentina

Australia

Bahamas

Barbados

Brazil

Bulgaria

Canada

China

Cyprus

Czech Republic

Denmark

Egypt

France

Germany

Greece

India

Indonesia

Italy

Jamaica

Japan

J ordan

K azakstan

Kenya

K orea

Malaysia

$M$ aldives

M exico

M orocco

$\mathrm{N}$ etherlands

Philippines

Poland

Russia

Saudi Arabia

South Africa

Spain

Sri Lanka

Sweden

Thailand

Tunisia

Turkey

U nited A rab Emirates

United $\mathrm{K}$ ingdom

U nited States

Venezuela
2003

8.199

1.035

2.050

12.108

8.938

0.500

2.611

0.543

0.605

5.391

1.061

0.923

3.852

1.355

0.369

4.569

0.720

0.977

1.426

6.483

0.283

2.850

0.636

1.697

0.385

0.839

11.604

0.899

3.379

0.474

0.639

0.950

0.499

n/a

1.544

3.031

1.136

0.674

1.405

2.434

3.167

n/a

0.832

1.387

0.194

\section{B alassa RCA Indices \\ Annual average 2000-2003}

8.118

1.166

1.667

11.489

8.318

0.448

2.345

0.535

0.802

5.697

0.985

0.964

3.790

1.299

0.411

4.690

0.734

1.152

1.389

5.980

0.154

2.893

0.676

1.566

0.481

0.899

11.062

0.795

3.360

0.446

0.743

1.317

0.499

$\mathrm{n} / \mathrm{a}$

1.274

2.919

0.805

0.655

1.450

2.700

3.012

$\mathrm{n} / \mathrm{a}$

0.801

1.394

0.242
Rank (by annual average)

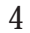

23

15

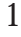

3

39

14

36

29

6

25

26

8

21

41

7

33

24

19

5

43

12

34

16

38

27

2

31

9

40

32

20

37

$\mathrm{n} / \mathrm{a}$

22

11

28

35

17

13

10

$\mathrm{n} / \mathrm{a}$

30

18

42

$\mathrm{N}$ ote: In a small number of cases, data were not available for all years over the period 2000-2003. In these cases, averages were calculated over the years for which data were available.

Sources: Tourism Factbook, World Tourism Organization and International Financial Statistics, International M onetary Fund. 
is, it is possible for both Spain and Thailand to reveal a disadvantage but still to be significant 'players' in international tourism if they are even more significant in the export of other goods or services. Tourism receipts accounted for less than 30\% of the total value of Spain's exports (2000-2003) and for less than $15 \%$ of Thailand's exports.

H owever, each individual measure of RCA has its own limitations. For this reason, it is common, as in this paper, to report more than one measure of revealed advantage. One key limitation of the Balassa Index is that it is based on export data only. It therefore risks overstating comparative advantage for those countries which are more open to international trade in general and understating advantage for those which are more closed to trade.

\section{Revealed comparative advantage - net export ratios}

Table 3 presents our calculations of the NER measure of RCA for our sample of countries. As with the Balassa Index, our results are presented both for the most recent year (2003) and for the annual average for the period 2000-2003. W here applicable, rankings are presented according to 2000-2003 annual averages to reflect the ordinal nature of revealed comparative advantage measures. NERs are also reported according to two separate bases of measurement - according to net receipts (that is, receipts from tourism less expenditure) and according to headcount (tourist arrivals less departures).

The N ER s based on net receipts (receipts from inbound tourists less expenditure by outbound) produce a set of results more in line with what one might expect. The most highly ranked countries according to the NER include only those known to be 'players' in world tourism - Jamaica, Tunisia, Bahamas, Barbados, M orocco, Spain, Cyprus, Egypt, Kenya and Thailand. A far greater number of countries are shown to 'reveal' an advantage. Of the sample of 44 countries, a total of 26 exhibit a revealed advantage according to the NER.

A number of countries known to have large tourist industries - G reece, Italy and M exico, for example - are not among the highest ranked countries according to the NER, but nonetheless exhibit a revealed advantage. The explanation for this is straightforward - although they do attract substantial receipts from incoming tourists, they also generate a significant volume of expenditure by their own outbound visitors.

There are few real surprises among those countries which 'reveal' an advantage according to the N ER (expenditure-based). There are, however, a few countries which reveal a disadvantage that, arguably, might not have been expected. These include, for example, Brazil and the United Arab Emirates. It is difficult to assess whether both of these countries do, in fact, generate substantial numbers of outbound visitors since neither reports data on arrivals and departures. It is, therefore, possible to identify three main possibilities only: (a) that there are significant measurement errors in the data for these countries; (b) these countries generate more outbound tourists than we expected; or (c) outbound tourists from these countries generate much higher expenditure per capita than from other countries. Of these possibilities, we would expect data measurement error to be the most likely.

Of our sample of countries, almost all reported data on receipts from inbound 
Table 3. Revealed comparative advantage - net export ratios.

\begin{tabular}{|c|c|c|c|c|c|c|}
\hline \multirow[b]{2}{*}{ Country } & \multicolumn{3}{|c|}{ B ased on expenditure } & \multicolumn{3}{|c|}{ Based on arrivals and departures } \\
\hline & 2003 & $\begin{array}{c}\text { Annual } \\
\text { average } \\
2000-2003\end{array}$ & $\begin{array}{c}\text { Rank (by } \\
\text { annual } \\
\text { average) }\end{array}$ & 2003 & $\begin{array}{c}\text { Annual } \\
\text { average } \\
\text { 2000-2003 }\end{array}$ & $\begin{array}{c}\text { Rank (by } \\
\text { annual } \\
\text { average) }\end{array}$ \\
\hline Argentina & 0.102 & -0.180 & 29 & $\mathrm{n} / \mathrm{a}$ & $\mathrm{n} / \mathrm{a}$ & $\mathrm{n} / \mathrm{a}$ \\
\hline Australia & 0.212 & 0.168 & 23 & 0.167 & 0.168 & 16 \\
\hline Bahamas & 0.708 & 0.733 & 2 & $\mathrm{n} / \mathrm{a}$ & $\mathrm{n} / \mathrm{a}$ & $\mathrm{n} / \mathrm{a}$ \\
\hline Barbados & 0.757 & 0.753 & 1 & $\mathrm{n} / \mathrm{a}$ & $\mathrm{n} / \mathrm{a}$ & $\mathrm{n} / \mathrm{a}$ \\
\hline Brazil & 0.046 & -0.189 & 31 & $\mathrm{n} / \mathrm{a}$ & $\mathrm{n} / \mathrm{a}$ & $\mathrm{n} / \mathrm{a}$ \\
\hline Bulgaria & 0.377 & 0.361 & 13 & 0.294 & 0.304 & 13 \\
\hline Canada & 0.112 & -0.073 & 27 & 0.374 & 0.422 & 10 \\
\hline China & 0.068 & 0.110 & 25 & 0.639 & 0.718 & 3 \\
\hline Cyprus & 0.523 & 0.597 & 7 & 0.587 & 0.637 & 5 \\
\hline Czech R epublic & 0.295 & 0.341 & 14 & 0.449 & 0.468 & 8 \\
\hline Egypt & 0.553 & 0.550 & 8 & 0.248 & 0.244 & 15 \\
\hline Germany & 0.470 & -0.486 & 37 & $\mathrm{n} / \mathrm{a}$ & $\mathrm{n} / \mathrm{a}$ & $\mathrm{n} / \mathrm{a}$ \\
\hline Greece & 0.504 & 0.397 & 12 & $\mathrm{n} / \mathrm{a}$ & $\mathrm{n} / \mathrm{a}$ & $\mathrm{n} / \mathrm{a}$ \\
\hline India & $\mathrm{n} / \mathrm{a}$ & $\mathrm{n} / \mathrm{a}$ & $\mathrm{n} / \mathrm{a}$ & -0.317 & -0.296 & 25 \\
\hline Indonesia & 0.134 & 0.203 & 19 & $\mathrm{n} / \mathrm{a}$ & $\mathrm{n} / \mathrm{a}$ & $\mathrm{n} / \mathrm{a}$ \\
\hline Italy & 0.206 & 0.243 & 17 & 0.403 & 0.444 & 9 \\
\hline J amaica & 0.686 & 0.694 & 5 & $\mathrm{n} / \mathrm{a}$ & $\mathrm{n} / \mathrm{a}$ & $\mathrm{n} / \mathrm{a}$ \\
\hline Japan & 0.532 & -0.714 & 38 & $\mathrm{n} / \mathrm{a}$ & $\mathrm{n} / \mathrm{a}$ & $\mathrm{n} / \mathrm{a}$ \\
\hline Jordan & 0.367 & 0.307 & 16 & 0.435 & 0.367 & 12 \\
\hline K azakstan & 0.085 & -0.114 & 28 & 0.156 & 0.160 & 17 \\
\hline K enya & 0.477 & 0.398 & 11 & $\mathrm{n} / \mathrm{a}$ & $\mathrm{n} / \mathrm{a}$ & $\mathrm{n} / \mathrm{a}$ \\
\hline K orea & 0.310 & -0.181 & 30 & -0.197 & -0.113 & 22 \\
\hline Malaysia & 0.349 & 0.421 & 9 & -0.328 & -0.250 & 24 \\
\hline M exico & 0.204 & 0.196 & 20 & 0.786 & 0.793 & 2 \\
\hline M orocco & 0.710 & 0.706 & 4 & 0.479 & 0.470 & 7 \\
\hline $\mathrm{N}$ etherlands & n/a & -0.256 & 33 & $\mathrm{n} / \mathrm{a}$ & $\mathrm{n} / \mathrm{a}$ & $\mathrm{n} / \mathrm{a}$ \\
\hline Philippines & 0.397 & 0.308 & 15 & $\mathrm{n} / \mathrm{a}$ & $\mathrm{n} / \mathrm{a}$ & $\mathrm{n} / \mathrm{a}$ \\
\hline Poland & 0.185 & 0.187 & 21 & 0.147 & 0.125 & 18 \\
\hline Russia & 0.482 & -0.459 & 36 & 0.048 & 0.069 & 20 \\
\hline South A frica & 0.270 & 0.204 & 18 & $\mathrm{n} / \mathrm{a}$ & 0.247 & 14 \\
\hline Spain & 0.669 & 0.681 & 6 & 0.905 & 0.901 & 1 \\
\hline Sri Lanka & 0.225 & 0.101 & 26 & 0.019 & -0.060 & 21 \\
\hline Sweden & 0.220 & -0.250 & 32 & $\mathrm{n} / \mathrm{a}$ & 0.111 & 19 \\
\hline Thailand & 0.382 & 0.416 & 10 & $\mathrm{n} / \mathrm{a}$ & 0.667 & 4 \\
\hline Tunisia & 0.681 & 0.713 & 3 & 0.414 & 0.486 & 6 \\
\hline Turkey & $\mathrm{n} / \mathrm{a}$ & n/a & $\mathrm{n} / \mathrm{a}$ & 0.406 & 0.399 & 11 \\
\hline United K ingdom & 0.361 & -0.329 & 34 & -0.426 & -0.418 & 26 \\
\hline United States & 0.170 & 0.175 & 22 & $\mathrm{n} / \mathrm{a}$ & $\mathrm{n} / \mathrm{a}$ & $\mathrm{n} / \mathrm{a}$ \\
\hline Venezuela & 0.453 & -0.381 & 35 & -0.313 & -0.196 & 23 \\
\hline
\end{tabular}

$N$ ote: (a) In a small number of cases, data were not available for all years over the period 2000-2003. In these cases, averages were cal culated over the years for which data were available; (b) D enmark, France, M aldives, Saudi Arabia and U nited A rab Emirates excluded as a result of no available data. Source: Tourism F actbook, W orld Tourism Organization. 
tourism and expenditure on outbound tourism, thus enabling NERs to be calculated on these data. H owever, far fewer of our sample reported data on tourist arrivals and departures. In consequence, NERs based on a headcount could be reported for a smaller sample only.

Using the NER based on headcount as a dichotomous measure of revealed advantage, it makes very little difference whether the NER is based on net receipts or on headcount. That is, al most all the countries that exhibit a revealed advantage based on net receipts also do so according to a net headcount. There are three main exceptions to this - Canada, Malaysia and Sweden. For Canada, and possibly the two other countries, the most likely explanation is that headcount figures are dominated by short-term cross-border visits by road, while receipts and expenditures figures are dominated by longer-term visitors by air or sea.

H owever, many countries in our sample either do not have road borders or do not have large volumes of cross-border visitors by road in relation to other visitors. These include, for example, Australia, Tunisia, Cyprus and Italy. It is interesting to note that: (a) these countries typically reveal an advantage or disadvantage according to both bases (net receipts and net headcount); but that (b) the value of the NER, and hence their ranking, is changed. For example, Australia exhibits higher values of the NER when measured according to expenditure than when measured by headcount. Since there is no cross-border road travel, this strongly suggests that the per capita spend by visitors to Australia is greater than the per capita spend by Australian visitors to other countries. Similar results can be observed for a number of other countries including, for example, Tunisia.

There are al so a number of examples of the reverse phenomenon. For instance, Spain exhibits a much higher value of the NER based on headcount than on net receipts. Assuming that the results are not dominated by measurement error, this would suggest that the per capita spend of Spain's inbound visitors is significantly lower than the per capita spend of its outbound visitors.

Taken overall, the comparison between N ER s based on net receipts and those based on net arrivals do suggest that important differences in the per capita spend of visitors to different countries exist. This, in turn, suggests that models of international trade which suggest specialization according to quality - see Falvey (1981) - are of potential relevance in understanding international tourism.

\section{Intra-industry trade - Grubel-Lloyd (static) Indices}

Table 4 presents Grubel-Lloyd Indices of IIT in tourism for our sample of countries. As with the results for NERs, these are presented on the basis of both net receipts (inbound receipts less outbound expenditure) and net headcount (arrivals less departures). Results are also presented for 2003 and for annual averages over the period 2000-2003, with rankings reported according to the latter.

For international trade in physical goods, IIT is usually highest between high-income developed economies. To the extent that international tourism is driven by the same forces of imperfect competition, product differentiation and 
Table 4. Grubel- Lloyd Indices of intra-industry trade.

\begin{tabular}{|c|c|c|c|c|c|c|}
\hline \multirow[b]{2}{*}{ Country } & \multicolumn{3}{|c|}{ Based on expenditure } & \multicolumn{3}{|c|}{ Based on arrivals and departures } \\
\hline & 2003 & $\begin{array}{c}\text { Annual } \\
\text { average } \\
2000-2003\end{array}$ & $\begin{array}{l}\text { Rank (by } \\
\text { annual } \\
\text { average) }\end{array}$ & 2003 & $\begin{array}{c}\text { Annual } \\
\text { average } \\
2000-2003\end{array}$ & $\begin{array}{c}\text { Rank (by } \\
\text { annual } \\
\text { average) }\end{array}$ \\
\hline Albania & 0.967 & 0.857 & 5 & $\mathrm{n} / \mathrm{a}$ & $\mathrm{n} / \mathrm{a}$ & $\mathrm{n} / \mathrm{a}$ \\
\hline Argentina & 0.898 & 0.820 & 8 & $\mathrm{n} / \mathrm{a}$ & $\mathrm{n} / \mathrm{a}$ & $\mathrm{n} / \mathrm{a}$ \\
\hline Australia & 0.788 & 0.832 & 6 & 0.833 & 0.832 & 7 \\
\hline Bahamas & 0.292 & 0.267 & 37 & $\mathrm{n} / \mathrm{a}$ & $\mathrm{n} / \mathrm{a}$ & $\mathrm{n} / \mathrm{a}$ \\
\hline Barbados & 0.243 & 0.247 & 38 & $\mathrm{n} / \mathrm{a}$ & $\mathrm{n} / \mathrm{a}$ & $\mathrm{n} / \mathrm{a}$ \\
\hline Brazil & 0.954 & 0.811 & 11 & $\mathrm{n} / \mathrm{a}$ & $\mathrm{n} / \mathrm{a}$ & $\mathrm{n} / \mathrm{a}$ \\
\hline Bulgaria & 0.623 & 0.639 & 22 & 0.706 & 0.696 & 13 \\
\hline Canada & 0.888 & 0.927 & 1 & 0.626 & 0.578 & 17 \\
\hline China & 0.932 & 0.890 & 3 & 0.361 & 0.282 & 24 \\
\hline Cyprus & 0.477 & 0.403 & 31 & 0.413 & 0.363 & 22 \\
\hline Czech R epublic & 0.705 & 0.659 & 21 & 0.551 & 0.532 & 19 \\
\hline Egypt & 0.447 & 0.450 & 30 & 0.752 & 0.756 & 9 \\
\hline Germany & 0.530 & 0.514 & 29 & $\mathrm{n} / \mathrm{a}$ & $\mathrm{n} / \mathrm{a}$ & $\mathrm{n} / \mathrm{a}$ \\
\hline Greece & 0.496 & 0.603 & 24 & $\mathrm{n} / \mathrm{a}$ & $\mathrm{n} / \mathrm{a}$ & $\mathrm{n} / \mathrm{a}$ \\
\hline India & n/a & n/a & $\mathrm{n} / \mathrm{a}$ & 0.683 & 0.704 & 12 \\
\hline Indonesia & 0.866 & 0.797 & 13 & $\mathrm{n} / \mathrm{a}$ & $\mathrm{n} / \mathrm{a}$ & $\mathrm{n} / \mathrm{a}$ \\
\hline Italy & 0.794 & 0.757 & 15 & 0.597 & 0.556 & 18 \\
\hline J amaica & 0.314 & 0.306 & 33 & $\mathrm{n} / \mathrm{a}$ & $\mathrm{n} / \mathrm{a}$ & $\mathrm{n} / \mathrm{a}$ \\
\hline Japan & 0.468 & 0.286 & 36 & $\mathrm{n} / \mathrm{a}$ & $\mathrm{n} / \mathrm{a}$ & $\mathrm{n} / \mathrm{a}$ \\
\hline Jordan & 0.633 & 0.693 & 18 & 0.565 & 0.633 & 14 \\
\hline K azakstan & 0.915 & 0.886 & 4 & 0.844 & 0.840 & 6 \\
\hline K enya & 0.523 & 0.602 & 25 & $\mathrm{n} / \mathrm{a}$ & $\mathrm{n} / \mathrm{a}$ & $\mathrm{n} / \mathrm{a}$ \\
\hline K orea & 0.690 & 0.819 & 9 & 0.803 & 0.887 & 4 \\
\hline Malaysia & 0.651 & 0.579 & 27 & 0.672 & 0.750 & 11 \\
\hline M exico & 0.796 & 0.804 & 12 & 0.214 & 0.207 & 25 \\
\hline M orocco & 0.290 & 0.294 & 34 & 0.521 & 0.530 & 20 \\
\hline $\mathrm{N}$ etherlands & $\mathrm{n} / \mathrm{a}$ & 0.744 & 17 & $\mathrm{n} / \mathrm{a}$ & $\mathrm{n} / \mathrm{a}$ & $\mathrm{n} / \mathrm{a}$ \\
\hline Philippines & 0.603 & 0.692 & 19 & $\mathrm{n} / \mathrm{a}$ & $\mathrm{n} / \mathrm{a}$ & $\mathrm{n} / \mathrm{a}$ \\
\hline Poland & 0.815 & 0.813 & 10 & 0.853 & 0.875 & 5 \\
\hline Russia & 0.518 & 0.541 & 28 & 0.952 & 0.931 & 2 \\
\hline South A frica & 0.730 & 0.796 & 14 & $\mathrm{n} / \mathrm{a}$ & 0.753 & 10 \\
\hline Spain & 0.331 & 0.319 & 32 & 0.095 & 0.099 & 26 \\
\hline Sri Lanka & 0.775 & 0.899 & 2 & 0.981 & 0.940 & 1 \\
\hline Sweden & 0.780 & 0.750 & 16 & $\mathrm{n} / \mathrm{a}$ & 0.889 & 3 \\
\hline Thailand & 0.618 & 0.584 & 26 & $\mathrm{n} / \mathrm{a}$ & 0.333 & 23 \\
\hline Tunisia & 0.319 & 0.287 & 35 & 0.586 & 0.514 & 21 \\
\hline Turkey & n/a & n/a & $\mathrm{n} / \mathrm{a}$ & 0.594 & 0.601 & 15 \\
\hline United K ingdom & 0.639 & 0.671 & 20 & 0.574 & 0.582 & 16 \\
\hline U nited States & 0.830 & 0.825 & 7 & $\mathrm{n} / \mathrm{a}$ & $\mathrm{n} / \mathrm{a}$ & $\mathrm{n} / \mathrm{a}$ \\
\hline Venezuela & 0.547 & 0.619 & 23 & 0.687 & 0.804 & 8 \\
\hline
\end{tabular}

$N$ ote: (a) In a small number of cases, data were not available for all years over the period 2000-2003. In these cases, averages were cal culated over the years for which data were available; (b) D enmark, France, M aldives, Saudi Arabia and U nited Arab Emirates excluded as a result of no available data. Source: Tourism F actbook, W orld Tourism Organization. 
scale economies, we might expect to observe a similar pattern in international tourism. As Table 4 shows, a number of the countries with the highest value of the Grubel-Lloyd Index (according to expenditure) are, indeed, developed economies - Canada, the N etherlands and the USA. But the majority of countries exhibiting the highest values of IIT are not high-income developed economies. For example, Indonesia, Sri Lanka and M exico all record high values of the index. Moreover, a number of countries with the lowest values of IIT are developed countries such as J apan and Germany.

Our results suggest, therefore, that the crude rule of thumb that IIT can be linked to income levels is questionable with respect to tourism. This does not, however, negate the relevance of IIT to tourism - the indices show IIT to be a significant component of overall trade for all countries. In only one case does two-way trade account for less than $30 \%$ of total trade. N or does it necessarily suggest that the underlying determinants of IIT, such as product differentiation, are of little relevance to tourism. On the contrary, the high values observed suggest that such influences are of considerable importance, even if they are not closely linked to income levels. This is not hard to explain - different locations are quite naturally differentiated in many ways (geographically, by climate and in culture, to name three) independently of income levels.

As with our analysis of N ERs, quite significant differences can arise for some countries between using expenditure and arrivals and departures as a basis for calculation. Since the Grubel-Lloyd Index can be expressed in terms of the $\mathrm{NER}$, this is not surprising and we offer no further comment than that provided earlier.

\section{Dynamic indices of intra-industry trade}

Table 5 presents the results of our analysis of the dynamic indices of IIT. That is, it presents results for the measure $A_{i j}, C_{i j}$ and $D_{i j}$, as described earlier. Unlike the preceding tables, these results are presented on the basis of outgoing and incoming travel expenditures only, and solely at the level of annual averages. That is, with three 'dynamic' measures of IIT, calculations based either on individual years or using arrivals and departures were excluded in the interests of clarity. For analytical purposes, we focus mainly on the $A_{i j}$ and $C_{i j}$ measures, which have the more transparent interpretation. The $D_{i j}$ is included for analytical completeness.

As with the static Grubel-Lloyd Index, we find that changes in total trade incorporate a high proportion of IIT (as measured by the $A_{i i}$ index) for a number of countries. These include, but by no means exclusively comprise, several developed countries. Thus, for example, the USA records a static Grubel-Lloyd Index of $0.825(2000-2003)$ and a value of $A_{i j}$ of 0.766 . Likewise, the figures for A ustralia are 0.832 and 0.715 . The results suggest, therefore, that IIT often accounts for a slightly smaller proportion of changes in international tourism than it does in existing levels.

As with the static indices, we find evidence of specialization in international tourism in terms of changes that broadly correspond with established patterns of specialization. For example, the (static) Grubel-Lloyd Index for Barbados is low at 0.247 , but the dynamic index $A_{i j}$ is even lower at 0.101 . This suggests 
Table 5. Dynamic measures of intra-industry trade.

\begin{tabular}{|c|c|c|c|}
\hline & & based or & hly) \\
\hline & $A_{i j}$ & $C_{i j}$ & $D_{i j}$ \\
\hline Albania & 0.696 & 0.055 & 0.018 \\
\hline Argentina & 0.581 & -0.015 & -0.073 \\
\hline Australia* & 0.715 & 0.247 & 0.106 \\
\hline Bahamas* & 0.247 & 0.070 & 0.004 \\
\hline Barbados & 0.101 & -0.003 & -0.065 \\
\hline Brazil & 0.051 & -0.085 & -0.208 \\
\hline Bulgaria & 0.651 & 0.090 & -0.036 \\
\hline Canada & 0.412 & 0.021 & -0.027 \\
\hline China* & 0.431 & -0.001 & -0.036 \\
\hline Cyprus & 0.700 & 0.000 & -0.016 \\
\hline Czech Republic & 0.566 & 0.026 & -0.027 \\
\hline Denmark & 0.727 & 0.035 & 0.007 \\
\hline Egypt & 0.137 & -0.011 & -0.088 \\
\hline France & 0.890 & 0.039 & 0.021 \\
\hline Germany & 0.683 & 0.018 & -0.038 \\
\hline Greece & 0.072 & 0.002 & -0.135 \\
\hline India* & 0.171 & 0.055 & -0.123 \\
\hline Indonesia* & 0.142 & -0.145 & -0.159 \\
\hline Italy & 0.539 & 0.034 & -0.015 \\
\hline J amaica & 0.282 & 0.022 & -0.044 \\
\hline Japan & 0.670 & 0.065 & -0.026 \\
\hline Jordan & 0.000 & 0.015 & -0.053 \\
\hline K azakstan & 0.761 & -0.003 & -0.027 \\
\hline Kenya & 0.325 & 0.044 & -0.076 \\
\hline K orea* & 0.412 & 0.174 & -0.073 \\
\hline M alaysi a* & 0.015 & -0.098 & -0.125 \\
\hline M aldives* & 0.091 & 0.197 & 0.003 \\
\hline M exico & 0.693 & 0.021 & -0.015 \\
\hline M orocco & 0.381 & 0.106 & -0.040 \\
\hline $\mathrm{N}$ etherlands & 0.863 & 0.027 & 0.015 \\
\hline Philippines & 0.553 & 0.033 & -0.070 \\
\hline Poland & 0.623 & -0.050 & -0.075 \\
\hline Russia & 0.404 & 0.088 & -0.068 \\
\hline South A frica & 0.460 & 0.084 & -0.048 \\
\hline Spain & 0.612 & 0.058 & -0.043 \\
\hline Sri Lanka & 0.301 & 0.113 & -0.083 \\
\hline Sweden* & 0.828 & 0.117 & 0.083 \\
\hline Thailand & 0.381 & 0.041 & -0.043 \\
\hline Tunisia & 0.290 & -0.008 & -0.049 \\
\hline Turkey & 0.235 & 0.072 & -0.113 \\
\hline United K ingdom* & 0.553 & 0.175 & 0.065 \\
\hline U nited States & 0.766 & -0.026 & -0.033 \\
\hline Venezuela & 0.782 & -0.003 & -0.026 \\
\hline
\end{tabular}

$\mathrm{N}$ ote: * indicates that the averages for this country were cal culated for less than the full sample of years because of missing data. 
that, for Barbados, the extent of IIT is declining. Likewise, Spain shows a low value of the static Grubel-Lloyd Index (0.319) and an even lower value (0.058) of the dynamic index $A_{i j}$.

The $C_{i j}$ index provides a clearer view of essentially the same phenomenon. For almost all countries, the changes in IIT are marginal in relation to total trade. For many countries, the change in IIT is marginally positive and, for a significant minority (including Barbados, Brazil, Indonesia and the USA), the change in IIT is negative. Taken overall, we conclude that the pattern of changes in IIT is broadly consistent with existing levels. In general, few countries exhibit significant changes in IIT. W here changes do occur, they tend to lead countries that are already specialized to further specialize, and countries that generate high volumes of IIT to move further in that direction.

\section{Conclusions}

In this paper, we have provided an analysis of international tourism using quantitative measurement techniques more usually associated with the study of international trade in goods. At the theoretical level, key concepts of international trade have al ready been linked to the economic theory of international tourism and, in consequence, such an approach al ready has solid foundations.

Our results suggest that using both the theory and the empirical techniques of international trade provides a useful contribution to furthering our understanding of international tourism. Our evidence suggests that many countries do, indeed, specialize as both 'exporters' and 'importers' of international tourism. A further implication of this is, therefore, that the determinants of such patterns of specialization may have common ground with those described by international trade theory (international differences in technology and factor endowments).

Finally, our results also strongly support the theoretical assertion that IIT is likely to be of importance in international tourism, both in terms of existing flows and for recent changes in international tourism. For the majority of countries in our sample, it is the dominant pattern of international exchange in tourism services. A key difference with IIT in physical goods does, however, exist. That is, our evidence on tourism does not support the view that IIT is largely a feature of high-income developed economies. Our results suggest IIT in tourism to be largely independent of the level of development. The most likely explanation of this is that, for tourism products, differentiation occurs quite naturally and does not need to be created within a high-income, consumer-oriented economy in the way that differentiation in goods does.

\section{References}

Bal assa, B. (1965), 'Trade liberal isation and "reveal ed comparative advantage"', T he M anchester School of Economic and Social Studies, Vol 33, pp 99-123.

Ballance, R.H. (1988), 'Trade performance as an indicator of comparative advantage', in Greenaway, D., ed, Economic D evelopment and International Trade, MacMillan, London, pp 199-221.

Ballance, R., Forstner, H., and Murray, T. (1986), 'Consistency tests of alternative measures of comparative advantage', R eview of Economics and Statistics, Vol 86, pp 157-161.

Brülhart, M. (1994), 'Marginal intra-industry trade: measurement and relevance for the pattern of industrial adjustment', Weltwirtschaftliches A rchiv, Vol 130, pp 600-613. 
Brülhart, M. (2001), 'D ynamics of intra-industry trade and labor-market adjustment', in Choi, E.K., and Greenaway, D., eds, G lobalization and Labor M arkets, Basil Blackwell, Oxford, pp 48-63.

Butler, R.W. (1980), 'T he concept of tourist area cycle of evolution: implication for management of resources', The Canadian G eographer, Vol 24, No 1, pp 5-16.

Butler, R.W. (2006), The Tourism A rea Life Cycle Volume 2, Conceptual and Theoretical Issues (A spects of Tourism), Channel View Publications, Clevedon.

Falvey, R.E. (1981), 'Commercial policy and international trade', Journal of International Economics, Vol 11, pp 495-511.

Gooroochurn, N., and Sugiyarto, G. (2005), 'Competitiveness indicators in the travel and tourism industry', Tourism Economics, Vol 11, No 1, pp 25-43.

Grubel, H.G., and Lloyd, P. J. (1975), Intra-Industry Trade, MacMillan, London.

$\mathrm{H}$ ardwick, P., and Webster, A. (2005), 'International trade in financial services', Services Industries J ournal, Vol 25, No 5, pp 85-103.

H azari, B., and Sgro, P. (2004), Trade and W elfare, Elsevier, Amsterdam.

International Monetary Fund (IMF), International Financial Statistics, www.imf.org.

Khan, H., and Lin, C.C. (2001), International Trade and Tourism: Evidence from Cointegration and Causality Test by U sing Singapore D ata, TTRA, USA.

Luzzi, G.F., and Fluckiger, Y. (2003), 'Tourism and international trade', Pacific E conomic R eview, Vol 8, No 3, pp 239-243.

Menon, J. (1996), 'The dynamics of intra-industry trade in ASEAN', A sian Economic J ournal, Vol 10, pp 123-142.

M enon, J., and Dixon, P. (1997), 'Intra-industry versus inter-industry trade: relevance for adjustment costs', Weltwirtschaftliches A rchiv, Vol 133, pp 164-169.

Shan, J., and Wilson, K. (2001), 'Causality between trade and tourism: empirical evidence from China', A pplied Economics Letters, Vol 8, pp 279-283.

Sinclair, M.T., and Stabler, M. (1997), The E conomics of Tourism, R outledge, London.

Toh, R.S., K han, H., and K oh, A. (2001), 'A travel balance approach for examining tourism area life cycles: the case of Singapore', J ournal of Travel Research, Vol 39, pp 426-432.

Turner, L.W., and Witt, S.F. (2001), 'Forecasting tourism using univariate and multivariate structural time series models', Tourism Economics, Vol 7, No 2, pp 135-147.

World Bank (2006), http://econ.worlabank.org.

W TO (2006), Tourism F actbook, 2006, www.wtoelibrary.org. 